\title{
Risk Factors for Developing Pressure Sore in Spinal Cord Injury (SCI) Patient's at CRP
}

\author{
Shirina Aktar*
}

Lecturer cum Demonstrator, Nursing department, CRP, Savar, Dhaka Bangladesh

DOI: $10.36348 /$ sjnhc.2020.v03i12.001 $\quad$ | Received: 16.11 .2020 | Accepted: 28.11 .2020 | Published: 05.12 .2020

*Corresponding author: Shirina Aktar

\section{Abstract}

Background: Pressure sore means localized injury of the skin \& underlying tissue usually over a bony prominence area due to pressure or pressure combined with shear \& fraction. Objectives: To identify the risk factors for developing pressure sore in spinal cord injury patient. Methodology: A case-control research design was carried out in this study; convenient sampling technique was used to collect the data from 50 participants among the SCI patients\& their attendants at CRP. A questionnaire was used to collect data and data was collected by face to face interview. Data were numerically coded and captured by using an SPSS 20.0 version software program and descriptive spastics was used for data analysis which focus to table, pie chart and bar chart. Results: In this research, 50 participants were participated. The factors significantly associated with the pressure sore were gender (OR- 8.500; 95\% CI, 2.338 to 30.908), knowledge about pressure sore (OR- 29.333; 95\% CI, 6.200 to 138.781),Personal hygiene (OR- .600; 95\% CI, .436 to .826), Sense of bowel \& bladder movement (OR- .360; 95\% CI, .213 to .607)\&bladder incontinence (OR- .240; $95 \%$ CI, .119 to .482)which is statistically significant, changing position 2 hourly (OR- 7.875; 95\% CI, 2.071 to 29.940), which is statistically significant, knowledge about proper transferring technique (OR- 4.125; 95\% CI, .961 to 17.704) \&avoid friction (OR- .360; 95\% CI,.213 to .607), which is statistically significant. So there is positive association between these factors \& pressure sore development in SCI patients. Conclusion: For developing sore in SCI patient some factors are greatly influenced. This factor helps to break down the skin \& developed pressure sore among the patient. So it is necessary to create more awareness \& provide more information about pressure sore \& possible risk factors among the SCI patients and their caregiver at CRP.

Keywords: Pressure sore, Spinal Cord Injury.

Copyright $\odot 2020$ The Author(s): This is an open-access article distributed under the terms of the Creative Commons Attribution 4.0 International License (CC BY-NC 4.0) which permits unrestricted use, distribution, and reproduction in any medium for non-commercial use provided the original author and source are credited.

\section{INTRODUCTION}

Spinal cord injury is one of the major physically disabling medical conditions which can leads to different impairments in participation in community reintegration [1]. The risk area for developing pressure sore in a spinal cord injury patient are - hips, buttocks, sacrum \& coccyx (tailbone), spine, heels, shoulders, ankles, back of head \& between the knee (legs rubbing together). The back of a patient's head may develop a pressure sore due to lying in a supine position for a prolonged period of time during and after surgery [2]. In a spinal cord injury patient pressure sore is the known secondary complication. In a spinal cord injury, pressure ulcer is the most costly complication, needs $25 \%$ of totals health care cost. Pressure sore creates some unfavorable effects including impair function rehospitalization, amputation \& infection. Numerous clinical notice \& research have shown that human trouble due to pressure sore which deeply effect on the usually physical health, socialization, economical status $\&$ image of the body etc [3]. Certain risk factors have been confirmed as predictive for pressure sore development which effect physical, emotional \& social overload for patients $\&$ their families [4]. The incidence and prevalence of pressure ulcers can be compared among general acute care facilities, long-term care facilities, and home care. The prevalence of pressure sore - the proportion of persons with pressure ulcers at a specific point in time - in general acute care setting is 10-18\%, long-term facilities $2.3-28 \%$, and home care from $0-29 \%$ [5]. External factors are the most significant factors for developing pressure sore in a spinal cord injury patient. Excessive pressure causes injury \& tears of the blood vessels. Pressure is the most important factor in pressure sore development. Tissue damage is caused by skin distortion resulting in occlusion of the blood vessels that leads to tissue 
necrosis and breakdown. Most pressure sore occur where the skin and tissues are directly compressed between bone and another hard surface such as floor, bed, chair, theatre table or trolley. Pressure damage can also occur when equipment is incorrectly applied as splints or bandages. There is no scientific agreement about the time and the given amount of pressure needs to be exerted before injury begins. Prolonged low pressure can be as harmful as short-term high pressure [6]. In a spinal cord injury patient pressure sore may also develop due to poor nutrition status. Patient needs enough fluids, calories, protein, vitamin \& minerals in their daily diets to maintain healthy skin \& prevent the breakdown of tissue [7]. Smoking is also another health related factors that increase the risk for developing pressure sore. Smoking reduced blood flow \& limits the amount of oxygen in the blood. For this reason it helps to develop more severe pressure sore \& heals more slowly [7].

\section{METHODOLOGY}

\section{Study design and participants}

A case-control study was selected for this research. In that method the close ended questionnaire \& face to face interview were taken with all participation of the well included spinal cord injury patient with pressure sore $\&$ their visitors or attendants. In this research we collect 50 participants for our study who were received pressure sore care in the spinal cord injury unit.

\section{RESULTS}

\section{Questionnaire}

For data collection, Bengali questionnaire will use. So that patient will understand the questionnaire in the easiest way. For data collections researcher will use close-ended structured questionnaire.

\section{Ethical issues and trial registration}

Researcher took approval from the ethical committee of nursing department to do the study. Then permission was taken from the In-charge of SCI unit for data collection from the patients by ensuring the safety of participants. The participant, who was interested to participate in the study, was informed verbally about the topic and purpose of study.

\section{DATA COLLECTION PROCEDURE}

The face to face interview technique was used to collect data. For this the materials to successfully complete the interview session and collected the valuable data from the participants were used such asquestion paper, consent form, pen, file, clip board etc. A structured questionnaire for collecting information related to the study was used. Data will be collected by a questionnaire set on a paper

\section{STATISTICAL ANALYSIS}

Data analysis is the process of systematically arranging \& presenting information in order to search for ideas. The aim of the data analysis is to find out the meaning of the collected information. Data were numerically coded using an SPSS 22.0 version software program. Data was analyzed through descriptive spastics who focused to table, pie chart and bar chart.

Table-01: Socio-demographics distribution of the respondents $(n=50)$

\begin{tabular}{|c|c|c|c|c|}
\hline & \multicolumn{2}{|c|}{ Frequency (n) } & \multicolumn{2}{|c|}{ Percentage (\%) } \\
\hline & Case & Control & Case & Control \\
\hline \multicolumn{5}{|c|}{ Age Distribution } \\
\hline $11-20$ & 10 & 4 & 40 & 16 \\
\hline $21-30$ & 4 & 9 & 16 & 36 \\
\hline $31-40$ & 6 & 7 & 24 & 28 \\
\hline 50 & 5 & 2 & 20 & 8 \\
\hline Above 50 years & 0 & 3 & & 12 \\
\hline \multicolumn{5}{|c|}{ Occupation } \\
\hline Farmer & 6 & 1 & 24 & 4 \\
\hline Tailor & 1 & & 4 & \\
\hline Carpenter & 1 & & 4 & \\
\hline Housewife & 0 & 14 & & 56 \\
\hline Students & 9 & 5 & 36 & 20 \\
\hline Others & 32 & 5 & 32 & 20 \\
\hline \multicolumn{5}{|c|}{ Residential Area } \\
\hline Urban & & 28 & & 56 \\
\hline Rural & & 22 & & 44 \\
\hline
\end{tabular}

\section{Case (Age)}

Among the 25 participants from whom data were collected the lowest age was 11 and highest age was more than 50 years. And frequency was $40 \%$ $(n=10)$ participants in between $11-20$ years, $16 \%(n=4)$ participants in between 21-30 years, 24\% (n=6) participants in between $31-40$ years, $20 \% \quad(n=5)$ participants are in 50 years. 


\section{Control (Age)}

Among the 25 participants from whom data were collected the lowest age was 11 and highest age was more than 50 years. And frequency was $16 \%(n=4)$ participants in between $11-20$ years, 36\% (n=9) participants in between 21-30 years, 28\% $(n=7)$ participants in between $31-40$ years, $8 \% \quad(n=2)$ participants in 50 years and $12 \%(n=3)$ participants are more than 50 years

\section{Case Occupation}

Among 25 participants the frequency of occupation was $24 \%(\mathrm{n}=6)$ participants were farmer, $4 \%(n=1)$ were tailor, $4 \%(n=1)$ were carpenter, $36 \%$ $(n=9)$ were students and $32 \%(n=32)$ were from other occupation.

\section{Control Occupation}

Among 25 participants the frequency of occupation was $4 \%(\mathrm{n}=1)$ participants were farmer, $56 \%$ were house wife's $(n=14), 20 \% \quad(n=5)$ were students and $20 \%(n=5)$ were from other occupation.

\section{Residential area}

The frequencies of residential area among 50 participants, 28 participants were urban and 22 participants were rural. The percentages were urban $56 \%$ and rural $44 \%$.

Table-2: Information about sex and pressure sore of participants.

\begin{tabular}{|l|l|l|l|}
\hline \multirow{2}{*}{ Sex of the participants } & \multicolumn{2}{|c|}{ Having pressure of the participants } & \multirow{2}{*}{ Total } \\
\cline { 2 - 3 } & Yes (Case) & No (control) & \\
\hline Male & 20 & 8 & 28 \\
\hline Female & 5 & 17 & 22 \\
\hline Total & $\mathbf{2 5}$ & $\mathbf{2 5}$ & $\mathbf{5 0}$ \\
\hline
\end{tabular}

Among the 50 participants $56 \%(\mathrm{n}=28)$ were male and $44 \% \%(n=22)$ were female. And among the 25 participants who were suffered from pressure sore (case) $80 \%(n=20)$ were male and $20 \%(n=5)$ were female, (Table 2).

Table-3: Information about presence of pressure sore and educational status

\begin{tabular}{|l|l|l|l|l|l|l|l|}
\hline \multirow{2}{*}{$\begin{array}{l}\text { Having pressure sore of } \\
\text { the participants }\end{array}$} & \multicolumn{2}{|c|}{ Educational level of the participants } & \multirow{2}{*}{ Total } \\
\cline { 3 - 8 } & Illiterate & Primary & S.S.C & H.S.C & $\begin{array}{l}\text { Masters \& } \\
\text { Above }\end{array}$ & \\
\hline \multirow{2}{*}{$\begin{array}{l}\text { Yes } \\
\text { (case) }\end{array}$} & Count & 10 & 6 & 9 & 0 & 0 & 25 \\
\hline \multirow{2}{*}{$\begin{array}{l}\text { No } \\
(\text { control) }\end{array}$} & Percentage & $40 \%$ & $24 \%$ & $36 \%$ & $0 \%$ & $0 \%$ & $100 \%$ \\
\hline \multirow{3}{*}{ Total } & Peunt & 6 & 7 & 8 & 2 & 2 & 25 \\
\cline { 2 - 8 } & Percentage & $24 \%$ & $28 \%$ & $32 \%$ & $8 \%$ & $8 \%$ & $100 \%$ \\
\hline
\end{tabular}

Among 50 participants from whom data were collected 25(case) participants had suffered from pressure sore \& 25(control) had no pressure sore. Among the 25(case) participant who had pressure sore $28 \% \quad(n=7)$ participants were illiterate, 24\% $(n=6)$ participants had primary education, $40 \% \quad(n=10)$ participants had SSC and $8 \%(n=2)$ participants HSC of educational status.Among the 25(control) participant who had no pressure sore $24 \%(n=6)$ participants were illiterate, $28 \%(n=7)$ participants had primary education, $32 \% \quad(n=8)$ participants had completed SSC and $8 \%(n=2)$ participants completed HSC \& $8 \% \quad(n=2)$ participant had Masters \& above of educational status (Table 4.2).

\section{Frequency of monthly family income}

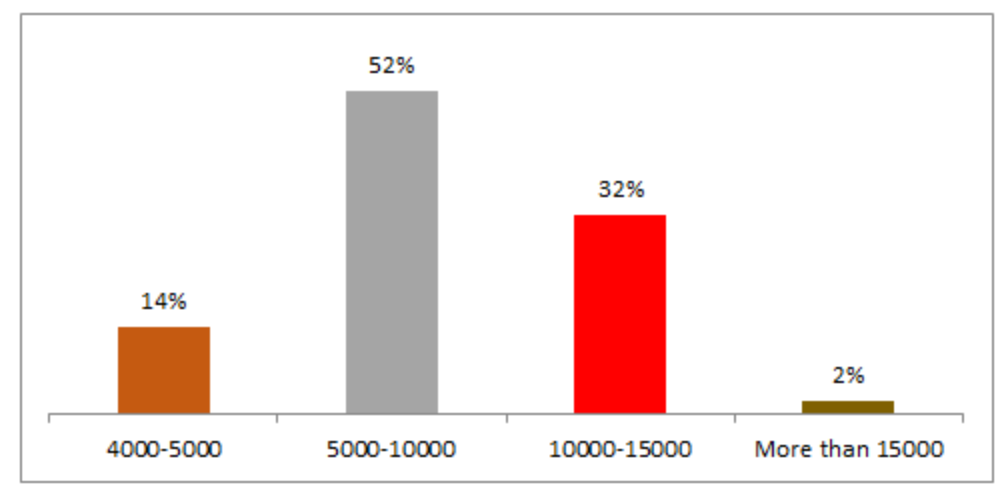

Fig-1: Frequency of monthly family income. 
Among 50 participants the frequency of monthly family income were that $14 \% \quad(n=7)$ participants earned monthly in range 4000-5000 taka, $52 \%(\mathrm{n}=26)$ participants earned monthly in range 6000 -
10000 taka, 32\% (n=16) participants earned monthly in range 10000-15000 taka and $2 \%(n=1)$ participants earned monthly $>15000$ taka (Figure 1).

\section{Frequency of site of pressure sore}

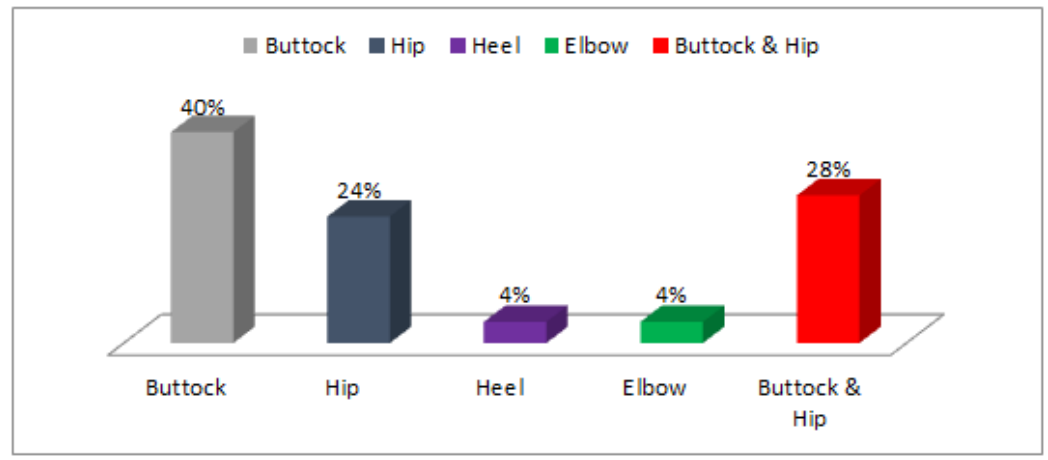

Fig-2: Frequency of the site of pressure sore.

Among 50 participants from whom data were collected 25(case) were suffering from pressure sore. The frequency of the site of pressure sore were $40 \%$ $(\mathrm{n}=10)$ participants got pressure sore in buttock, $24 \%$ $(n=6)$ participants got pressure sore in hip and $4 \%(n=1)$ participants got pressure sore in heel \& $4 \% \quad(n=1)$ participants got pressure sore in elbow \& $28 \%(n=7)$ participants got pressure sore in buttock \& hip (Figure 02).

Table-4: Information about sense of bowl and bladder movement of the participants

\begin{tabular}{|c|c|c|c|}
\hline \multirow{2}{*}{\multicolumn{2}{|c|}{ Having pressure sore of the participants }} & \multicolumn{2}{|c|}{ Sense of bowel \& bladder movement } \\
\hline & & Yes & No \\
\hline \multirow{2}{*}{$\begin{array}{l}\text { Yes } \\
\text { (case) }\end{array}$} & Count & 8 & 17 \\
\hline & Percentage & $32 \%$ & $68 \%$ \\
\hline \multirow{2}{*}{$\begin{array}{l}\text { No } \\
\text { (control) }\end{array}$} & Count & 25 & 0 \\
\hline & Percentage & $100 \%$ & $0 \%$ \\
\hline \multirow[t]{2}{*}{ Total } & Count & 33 & 17 \\
\hline & Percentage & $66 \%$ & $34 \%$ \\
\hline
\end{tabular}

Among 50 participants from whom data were collected 25(case) participants had suffered from pressure sore \& 25(control) had no pressure sore. Among 25 participants who suffered from pressure sore $32 \%(n=8)$ participants had the sense of bowl and bladder movement and $68 \%(\mathrm{n}=17)$ participants had no sense of bowl and bladder movement.

\section{Information about duration of position changing} during lying

Among 50 participants from whom data were collected 25(case) participants had suffered from pressure sore $\& 25$ (control) had no pressure sore. The 25 participants who suffered from pressure sore among them $68 \%(\mathrm{n}=17)$ change position in every $0-2$ hours, $24 \%(n=6)$ change position in $2-4$ hours, $4 \%(n=61)$ change position 4-6 hourly and $4 \%(n=1)$ participants not know. And the 25 participants who had no pressure sore among them $0 \%(\mathrm{n}=0)$ change position in every 0 2 hours, $36 \%(\mathrm{n}=9)$ change position in $2-4$ hours, $36 \%$ $(\mathrm{n}=9)$ change position 4-6 hourly and $28 \% \quad(\mathrm{n}=7)$ participants not know.

Table-5: Information duration of position change of the participants.

\begin{tabular}{|c|c|c|c|c|c|c|}
\hline \multirow{2}{*}{\multicolumn{2}{|c|}{ Having pressure sore of the participants }} & \multicolumn{4}{|c|}{ Duration of position change during lying } & \multirow[t]{2}{*}{ Total } \\
\hline & & 0-2 hours & 2-4 hours & 4-6 hours & Not know & \\
\hline \multirow[t]{2}{*}{ Yes (case) } & Count & 17 & 6 & 1 & 1 & 25 \\
\hline & Percentage & $68 \%$ & $24 \%$ & $4 \%$ & $4 \%$ & $100 \%$ \\
\hline \multirow{2}{*}{$\begin{array}{l}\text { No } \\
\text { (control) }\end{array}$} & Count & 0 & 9 & 9 & 7 & 25 \\
\hline & Percentage & $0 \%$ & $36 \%$ & $36 \%$ & $28 \%$ & $100 \%$ \\
\hline \multirow[t]{2}{*}{ Total } & Count & 18 & 11 & 9 & 12 & 50 \\
\hline & Percentage & $36 \%$ & $22 \%$ & $18 \%$ & $24 \%$ & $100 \%$ \\
\hline
\end{tabular}




\section{Risk Factors associated with developing pressure sore in SCI patient}

This study was a case control study and the mode of association between pressure sore and risk factors was Odds ratio. 95\% confidence interval was calculated for finding out the significant of the association. If 1 came between the lower bound and the upper bound of confidence interval it was considered as non-significance.

\section{Presence of pressure sore $\&$ gender}

The Odds ratio for both sex of the study was 8.500 suggesting pressure sore is 8.500 times as frequent in the case compared with the control. The confidence interval of odds ratio was ranging from 2.338 to 30.908 which don't span 1 indicating that this association was significant.

\section{Knowledge of pressure sore \& developing pressure sore}

The Odds ratio for knowledge about pressure sore of the study was 29.333 suggesting pressure sore is 29.333 times as frequent in the case compared with the control. The confidence interval of odds ratio was ranging from 6.200 to 138.781 indicating that this association was significant.

\section{Personal hygiene \& developing pressure sore}

The Odds ratio for Personal hygiene of the study was .600 suggesting pressure sore is .600 times as frequent in the case compared with the control. The confidence interval of odds ratio was ranging from .436 to .826 which don't span 1 indicating that this association was significant.

\section{Presence of pressure sore \& Sense of bowel \& bladder movement}

The Odds ratio for Sense of bowel \& bladder movement of the study was .360 suggesting pressure sore is .360 times as frequent in the case compared with the control. The confidence interval of odds ratio was ranging from .213 to .607 which don't span 1 indicating that this association was significant.

\section{Presence of bladder incontinence \& developing pressure sore}

The Odds ratio for presence of bladder incontinence of the study was .240 suggesting pressure sore is .240 times as frequent in the case compared with the control. The confidence interval of odds ratio was ranging from .119 to .482 indicating that this association was significant.
Presence of pressure sore \& used urinary catheter 2 hourly

The Odds ratio for use urinary catheter 2 hourly of the study was .640 suggesting pressure sore is .640 times as frequent in the case compared with the control. The confidence interval of odds ratio was ranging from .477 to .859 indicating that this association was significant.

\section{Changing position 2 hourly \& developing pressure} sore

The Odds ratio for changing position 2 hourly of the study was 7.875 suggesting pressure sore is 7.875 times as frequent in the case compared with the control. The confidence interval of odds ratio was ranging from 2.071 to 29.940 indicating that this association was significant.

\section{Taking lift properly \& developing pressure sore}

The Odds ratio for taking lift properly of the study was .720 suggesting pressure sore is .720 times as frequent in the case compared with the control. The confidence interval of odds ratio was ranging from .564 to .919 indicating that this association was significant.

\section{Knowledge about proper transferring technique \& developing pressure sore}

The Odds ratio for Knowledge about proper transferring technique of the study was 4.125 suggesting pressure sore is 4.125 times as frequent in the case compared with the control. The confidence interval of odds ratio was ranging from .961 to 17.704 which span 1 indicating that this association was not significant.

\section{Avoid friction \& presence of pressure sore}

The Odds ratio for avoid friction of the study was .360 suggesting pressure sore is .360 times as frequent in the case compared with the control. The confidence interval of odds ratio was ranging from .213 to .607 which don't span 1 indicating that this association was significant.

\section{Presence of pressure sore \& Suffering with illness after SCI}

The Odds ratio for Suffering with illness after SCI of the study was .880 suggesting pressure sore is .880 times as frequent in the case compared with the control. The confidence interval of odds ratio was ranging from .761 to 1.017 indicating that this association was not significant. 
Table-6: Information about Risk factors for pressure sore development of the participants

\begin{tabular}{|c|c|c|c|c|c|c|}
\hline \multicolumn{2}{|l|}{ Variable } & \multirow{3}{*}{$\begin{array}{l}\text { Case } \\
20 \\
5\end{array}$} & \multirow{3}{*}{$\begin{array}{l}\text { Control } \\
8 \\
17\end{array}$} & \multirow{3}{*}{$\begin{array}{l}\text { OR } \\
8.50\end{array}$} & \multicolumn{2}{|c|}{$95 \% \mathrm{CI}$} \\
\hline & & & & & Lower & Upper \\
\hline Sex & $\begin{array}{l}\text { Male } \\
\text { Female }\end{array}$ & & & & 2.33 & 30.90 \\
\hline Knowledge about pressure sore & $\begin{array}{l}\text { Yes } \\
\text { No }\end{array}$ & $\begin{array}{l}20 \\
5\end{array}$ & $\begin{array}{l}11 \\
14\end{array}$ & 29.33 & 6.20 & 138.78 \\
\hline Maintain personal hygiene & $\begin{array}{l}\text { Yes } \\
\text { No }\end{array}$ & $\begin{array}{l}15 \\
10\end{array}$ & $\begin{array}{l}25 \\
0\end{array}$ & .60 & .43 & .82 \\
\hline Changing position 2 hourly & $\begin{array}{l}\text { Yes } \\
\text { No }\end{array}$ & $\begin{array}{l}21 \\
4\end{array}$ & $\begin{array}{l}10 \\
15\end{array}$ & 7.87 & 2.07 & 29.94 \\
\hline Sense of bowel bladder movement & $\begin{array}{l}\text { Yes } \\
\text { No }\end{array}$ & $\begin{array}{l}8 \\
17\end{array}$ & $\begin{array}{l}25 \\
0\end{array}$ & .36 & .21 & .60 \\
\hline Bladder incontinence & $\begin{array}{l}\text { Yes } \\
\text { No }\end{array}$ & $\begin{array}{l}19 \\
6\end{array}$ & $\begin{array}{l}0 \\
25\end{array}$ & .24 & .11 & .48 \\
\hline Using Catheter after 2 hours & $\begin{array}{l}\text { Yes } \\
\text { No }\end{array}$ & $\begin{array}{l}9 \\
16\end{array}$ & $\begin{array}{l}0 \\
25\end{array}$ & .64 & .47 & .85 \\
\hline Taking lift properly during Using Wheelchair & $\begin{array}{l}\text { Yes } \\
\text { No }\end{array}$ & $\begin{array}{l}7 \\
18\end{array}$ & $\begin{array}{l}0 \\
25\end{array}$ & .72 & .56 & .91 \\
\hline Knowledge about proper transferring technique & $\begin{array}{l}\text { Yes } \\
\text { No }\end{array}$ & $\begin{array}{l}9 \\
16\end{array}$ & $\begin{array}{l}8 \\
17\end{array}$ & 4.12 & .96 & 17.70 \\
\hline Avoid friction & $\begin{array}{l}\text { Yes } \\
\text { No }\end{array}$ & $\begin{array}{l}8 \\
17\end{array}$ & $\begin{array}{l}25 \\
0\end{array}$ & .32 & .18 & .56 \\
\hline Suffering from illness after SCI & $\begin{array}{l}\text { Yes } \\
\text { No }\end{array}$ & $\begin{array}{l}3 \\
22\end{array}$ & $\begin{array}{l}0 \\
25\end{array}$ & .88 & .76 & 1.01 \\
\hline
\end{tabular}

\section{DISCUSSION}

The present study used a case-control design to find out the risk factors for developing pressure sore among the SCI patients in CRP. The results of this study showed that various factors are responsible for developing pressure sore among the participants such as unhygienic condition, no sense of bowel bladder movement, bladder incontinence, friction, etc. In this study, It was found that male were more affected than female the percentage of male and female who suffered from pressure sore were $80 \%$ male and $20 \%$ female; as male were more got spinal cord injury than female.

In this study most of the participants came from the urban area which was about $56 \%$ and had a low socioeconomic status. Majority had the monthly income that $14 \%$ participants earned monthly in range of 4000-5000 taka, 52\% participants earned monthly in range of 6000-10000 taka, $32 \%$ participants earned monthly in range of 10000-15000 taka, 2\% participants earned monthly in range of $>15000$ taka and most of them had only one earning member in their family. Maximum participants of this study were students; it was $36 \% \& 32 \%$ participants were other occupations.

This study showed that the participants who were suffering from pressure sore had a lower educational status. Here $40 \%$ participants who were suffering from pressure sore were illiterate and $24 \%$ participants were primary \& $36 \%$ had S.SC educational knowledge. In this study it was also found that $40 \%$ pressure sore seen in between 11-20 years of age, $16 \%$ in between 21-30 years, $24 \%$ in between $31-40$ years and, $20 \%$ in between $41-50$ years. So it is seen that teenage person were more affected. Among 50 participants from whom data were collected 25 were suffering from pressure sore. This study showed that unhygienic condition of the participants also helps to develops pressure sore in SCI patient. Among 25 participants $60 \%$ were maintain personal hygiene \& $40 \%$ didn't maintain personal hygiene.

Among 50 participants from whom data were collected 25 were suffering from pressure sore. The frequencies of the site of pressure sore were buttock $40 \%$, hip $24 \%$ \& both were $28 \%$ and heel $4 \%$. Literature said that approximately 70 percent of pressure ulcers develop on the sacral prominence, or lower back. This is due to a bedridden patient not being turned on the side at least every two hours and approximately, 15 percent of pressure ulcers develop on the lower extremities [2].

This study showed that among 50 participants 25 were suffering from pressure sore the frequency of changing position 2 hourly was $68 \%$ did not change position 2 hourly was $32 \%$. Changing patient's positions is the most important factor for Pressure sore development. Changing patient's positions fewer than 6 times a day increases the risk of PU development. The main purpose of PU prevention is to reduce pressure and degree of constant pressure. One of the most important interventions provided to achieve this aim of changing patient's positions [8]. 
Among 50 participants 25 were suffering from pressure sore the frequency of taking lift during using wheelchair were that $28 \%$ participants took lift properly and $72 \%$ participants did not take lift properly because they did not use wheelchair. It is also risk factors for developing sore in SCI patient.

This study showed that pressure sore was commonly seen in the participants who had no sense of bowl and bladder movements. The participants who had pressure sore among them $32 \%$ had the sense about bowel and bladder movements and $68 \%$ had no sense about bowel and bladder movements. So it was seems that incontinence is one of the risk factor of the risk factor for developing pressure sore at the CRP. The literature said that problems with bladder control can greatly increase the risk of pressure sores because the skin may frequently be moist, making it more likely to break down [9].

In this study it was found that participants who were suffering from pressure sore among them only $36 \%$ participants had the knowledge of proper transferring technique and $64 \%$ had no knowledge about proper transferring techniques. Lack of knowledge about proper transferring may increase the patients risk to develop pressure sore. According to literature if anyone have trouble to transferring into wheelchair, have risk for developing pressure sore, $\&$ it is important to know about the technique to prevent pressure sore [10].

In This study it is found that friction may be one of the risk factors for developing pressure sore at CRP but there was a doubt as this study showed that most of the participants avoid friction. Among 25 participants who had pressure sore $32 \%$ avoid friction and $68 \%$ did not avoid friction. Friction also a risk factors for pressure sore development in SCI patient [11].

\section{CONCLUSION}

In Bangladesh still there have scarcity of proper management of Spinal cord injury. People with SCI are vulnerable across their lifespan to tissue breakdown or pressure sore that can interfere with initial rehabilitation in the acute post-traumatic recovery phase and successful reintegration into the communities, as well as lead to more serious medical complications. So it is necessary to create more awareness \& provide more information about pressure sore \& possible risk factors among the SCI patients and their caregiver at CRP.

\section{ACKNOWLEDGMENTS}

I would like to pay my highest gratitude to my honorable supervisor Ehsanur Rahman, Assistant
Professor, Department of physiotherapy, BHPI, CRP, Savar, Dhaka

\section{REFERENCES}

1. Ramakrishnan, K., Loh, S. Y., \& Omar, Z. (2011). Earnings among people with spinal cord injury. Spinal Cord, 49(9), 986-989.

2. Poledníková, L., \& Slamková, A. (2016). AT RISK OF PRESSURE ULCERS-A NURSING DIAGNOSIS. Central European Journal of Nursing and Midwifery, 7(2), 428-436.

3. Henzel, M. K., \& Ho, C. H. (2011). Pressure ulcer management and research priorities for patients with spinal cord injury: consensus opinion from SCI QUERI Expert Panel on Pressure Ulcer Research Implementation. Journal of rehabilitation research and development, 48(3), XI.

4. National Pressure Ulcer Advisory Panel. (2014). Prevention and treatment of pressure ulcers: clinical practice guideline. Cambridge Media.

5. Dorner, B., Posthauer, M. E., \& Thomas, D. (2009). The role of nutrition in pressure ulcer prevention and treatment: National Pressure Ulcer Advisory Panel white paper. Advances in skin \& wound care, 22(5), 212-221.

6. Lyder, C. H. (2003). Pressure ulcer prevention and management. Jama, 289(2), 223-226.

7. Bedsores (pressure ulcers) - Symptoms and causes [Internet]. (2020). Mayo Clinic. 2020 [cited 20 November 2020]. Available from: https://www.mayoclinic.org/diseasesconditions/bed-sores/symptoms-causes/syc20355893

8. Bedsores (pressure ulcers) - Symptoms and causes [Internet]. (2020). Mayo Clinic. 2020 [cited 20 November 2020]. Available from: https://www.mayoclinic.org/diseasesconditions/bed-sores/symptoms-causes/syc20355893

9. Prentice, J. L., Stacey, M. C., \& Lewin, G. (2003). An Australian model for conducting pressure ulcer prevalence surveys. Primary Intention: The Australian Journal of Wound Management, 11(2), 87.

10. Encyclopedia, M., ulcers, P. (2020). Preventing pressure ulcers: MedlinePlus Medical Encyclopedia [Internet]. Medlineplus.gov. 2020 [cited 20 November 2020]. Available from: https://medlineplus.gov/ency/patientinstructions/00 0147.htm

11. Kaitani, T., Tokunaga, K., Matsui, N., \& Sanada, H. (2010). Risk factors related to the development of pressure ulcers in the critical care setting. Journal of clinical nursing, 19(3-4), 414421. 